\title{
Management and Maintenance of University Multimedia Voice Classroom
}

\author{
Xiaomei $\mathrm{Yu}^{1}$ \\ ${ }^{1}$ Multimedia Voice Classroom laboratory, Eastern Liaoning University, Liaoning, China. \\ Correspondence: Xiaomei Yu, Multimedia Voice Classroom laboratory, Eastern Liaoning University, Liaoning, China.
}

Received: June 2, 2016

Accepted: June 13, 2016

Available online: June 23, 2016

doi:10.11114/ijsss.v4i8.1689

URL: http://dx.doi.org/10.11114/ijsss.v4i8.1689

\begin{abstract}
As an important part of teaching infrastructure, the management and maintenance of university multimedia Voice classroom has a direct impact on the conduct of university teaching.
\end{abstract}

Keywords: Multimedia Voice classroom, Management, Maintenance

\section{Introduction}

With the rapid development of computer network technology, and the organic integration of educational processes, multimedia assisted teaching devices are becoming a new and increasing addition to the traditional means of teaching aids. And, in order to ensure the orderly conduct and improvement of teaching methods, and to continuously improve the quality of graduating students, universities must continue to improve multimedia voice classroom teaching equipment, and to ensure its proper management.

Given the high level of multimedia assisted teaching methods in modern teaching techniques, university multimedia voice classroom management, and maintenance, is becoming an important part of teaching management in universities. As such, it is necessary to explore the current management and maintenance of multimedia classrooms, and then to examine a proposed increase in multimedia voice classroom management and maintenance, to further improve teaching levels.

\subsection{The importance of multimedia voice equipment management and maintenance.}

Normal and efficient operation of multimedia voice equipment is a necessary condition for the modernization of multimedia education colleges and universities, especially for more specialized foreign language colleges. With the rapid development of computer network technology, multimedia classroom voice and other multimedia equipment in the 1990s began to enter college teaching. It has played an increasingly important role in recent years, along with other emerging multimedia devices. Many universities have also sought to strengthen the effective management and maintenance of multimedia equipment. However, their efforts have been hampered by the shortage of quality management and maintenance personnel and recognition of the importance of these functions.

\subsection{The growth in college and university multimedia voice classrooms.}

The gradual expansion of multimedia teaching in colleges and universities has led to a corresponding increase in the number of college degree multimedia voice classrooms. With this growth in multimedia teaching, there is a need to ensure the smooth progress of traditional teaching methods without restricting the further increase of multimedia teaching levels.

\section{Management and Maintenance}

\subsection{Current multimedia voice classroom management and maintenance models.}

Currently, the responsibilities are held by Academic Affairs, Logistic Departments or shared by Education/Logistic Departments. The latter model is the one that is predominately used, although it can lead to communication and responsibility issues.

\subsection{Procurement-related equipment issues.}

Due to the lack of sound procurement systems, there have been many issues relating to the compatibility of multimedia devices. This has occurred as a result of the purchase of different brand devices leading to the disruption of normal and orderly multimedia voice teaching. 


\subsection{Lack of well-qualified management and maintenance personnel.}

The rapid development of high-level multimedia technology equipment has lead to a need for high-quality personnel to manage and maintain the multimedia equipment. Devices. However, the reality is that colleges and universities lack the necessary personnel to carry out these functions. "the big issue about management personnel is in quantity and quality. According to the survey, the staff quantity is generally low due to limited preparation." ${ }^{[1]}$.Their response has generally been to use teaching staff from within The Schools of Computer Science. This creates a heavy burden on the teaching and research work of teachers, whilst being not conducive to efficient multimedia voice classroom management and maintenance.

\subsection{The effects of improper update and maintenance of equipment}

Teachers often use multimedia teaching equipment on a daily basis. For optimum use, equipment needs to properly operated, maintained and its software updated in accordance with manufacturers standards. This brings challenges for teachers especially those who may be older and less technologically skilled. It may result in equipment failure, disruptions to teaching programs and a reduction in the useful life of equipment.

\subsection{Lack of long-term and systematic maintenance}

Although the use of multimedia of teaching devices has become more common university management focus is still generally concentrated in the traditional fields of student management and traditional teaching methodologies. This is illustrated by a lack of long-term maintenance and systematic planning resulting in malfunction and a disruption to teaching programs using multimedia devices.

\subsection{The high cost of purchasing, operating and maintaining multimedia devices}

In general, the costs of purchasing, operating and maintaining multimedia equipment are placing increasing cost pressures on University budgets. This can lead to the purchase of non-standard and incompatible equipment resulting in maintenance issues and teaching disruption.

\section{Colleges and universities to strengthen the management and maintenance of multimedia classrooms voice search path}

Universities from change management to enhance the multimedia voice classroom management and maintenance service concept, strengthen and improve relevant systems construction, management and maintenance to improve the quality of personnel, the reasonable control of the respective channel management and maintenance costs at the same time start in an orderly manner, improve the multimedia voice Universities management and maintenance of the level of the classroom.

1) The concept of change management and maintenance, maintenance concept from the past failures of management to manage predictive maintenance concept change. Concept is the precursor of action to strengthen the voice of Multimedia classroom management and maintenance, and effectively improve the level of management and maintenance of the equipment, it must first reverse the positive management and maintenance philosophy start, fault management focus from predictive maintenance concept to management and maintenance concept change, the so-called failure of management and maintenance of the idea that the traditional device management and maintenance in the presence of ex-post management and maintenance method of philosophy, that is, only when the associated device is faulty or there is significant hidden faults when it is to carry out equipment maintenance and management, often is a "passive" management and maintenance concept, management and maintenance of this concept is often only a temporary solution to problems related to equipment failure, to the detriment of long-term normal use of related equipment; and predictive maintenance management philosophy is the organic combination of failure in advance, using the process and post management and maintenance carried out, focusing on equipment management and maintenance of global and integrity, outstanding performance by its professionals to create dynamic tracking mechanism for long-term use of related equipment establish and strengthen institutionalized since daily assessment of associated multimedia devices, and timely records, the use of the equipment, management and maintenance of long-term, predictable management and maintenance, maintenance, maintenance of way under this philosophy guided more conducive to ensure proper and efficient use of the multimedia device. With the rapid development of modern educational technology, multimedia voice and efficient equipment is also increasingly showing the complexity and diversity of distinctive characteristics, management and maintenance of the traditional concept of fault can not satisfy the management of Multimedia voice equipment and maintenance work, which has prompted Universities multimedia voice classroom management and predictive maintenance concept to maintenance of change management has been very urgent, it should be the future of University of multimedia voice classroom multimedia equipment management and maintenance oriented philosophy.

2) Strengthen the system construction; establish a complete and efficient system of multimedia voice classroom 
management and maintenance system of System of Universities. "Gradually improve multimedia classrooms voice network management system, develop management regulations multimedia teaching platform, ${ }^{[2]}$.Institutional system to ensure that the complete system is an effective multimedia voice classroom Universities effective management and maintenance of an important guarantee for the effective guarantee the normal order of teaching universities, colleges and universities should earnestly study relevant systems, to develop and improve the work, so as to establish compliance with the school the actual management needs to improve the system of multimedia classroom voice and other multimedia equipment and maintenance of institutional system, to perfect the reform of the existing multimedia voice classroom management system, the establishment by the school related to the leadership to take charge of the coordination of other departments to give support multimedia equipment management and maintenance office, including colleges and universities, including multimedia classrooms voice, unified school is responsible for everything from multimedia equipment procurement, management and maintenance and a series of management and coordination of the whole process, to strengthen the voice of multimedia classrooms and other multimedia devices in use various types of collection, analysis of information, and strengthen the related equipment used to monitor, to find all kinds of potential problems that may exist promptly organize relevant personnel to repair and maintenance, the management and maintenance responsibilities to the individual, thereby enhancing management and maintenance level of university multimedia voice classroom multimedia equipment, effectively ensure the normal operation of multimedia Teaching.

3) Strengthen technical mastery and technological innovation and other related multimedia voice classroom multimedia equipment, multimedia equipment to improve the overall level of management and maintenance. Technical factors are important factors Colleges voice classroom multimedia equipment management and maintenance of the level of improvement, but also affect Colleges voice classroom management and maintenance costs low key ring, colleges and universities should be fully aware of the technical factors in University multimedia classroom voice, multimedia equipment management and maintenance of vital significance, and effectively improve the technology to enhance the voice of University classrooms and other multimedia equipment, professional and technical personnel, and continuously improve their professional skills, can maintain a person through the introduction of new high-quality equipment management, to strengthen the existing multimedia Universities training equipment and technical personnel, and actively carry out school-enterprise cooperation related businesses to encourage school multimedia devices into the enterprise management and maintenance personnel to learn, observe and so on, strengthen technology to master basic literacy and school professionals multimedia equipment, so as to properly multimedia Teaching undertaken to provide a solid technical support.

4) Rational Control of multimedia voice classroom multimedia equipment management and maintenance costs, improve capital utilization. Scientific and reasonable cost control multimedia devices and universities, to strengthen supervision of the use of the relevant funds are able to make efficient use of every penny, this is an important part of strengthening the voice of Multimedia classroom management and maintenance. Cost Control in Universities multimedia voice classroom multimedia equipment related to the daily management of budgeting related equipment procurement eve of funds invested, equipment procurement, equipment and maintenance of equipment scrapped until the whole process, every aspect of the need to invest a lot of money, so we must strengthen the relevant aspects of the process of cost control, improve capital utilization. Face of many universities and other multimedia voice classroom multimedia equipment management and maintenance costs are too high, the reality of low utilization of funds, colleges and universities should actively through the whole process of cost control related equipment into the overall development plan of colleges and universities, to strengthen the relevant funds from the budget to monitoring the course of the ways to strengthen cost control, equipment management and maintenance of the "low-input, high output," such as colleges and universities can organize school multimedia equipment management and maintenance personnel do well in the course of routine maintenance good multimedia equipment management and maintenance of records of the daily management and maintenance of multimedia devices research and analysis, to grasp the laws of multimedia equipment failure occurs, perform predictive management and maintenance in accordance with the law of its possible failure, reducing maintenance costs.

5) To strengthen the multimedia classroom voice, multimedia voice equipment management and maintenance personnel as well as training and education of teachers groups safe operation, ensure normative operation of the device. "As a multi-service window

Media classrooms voice managers must first establish a correct concept of the need to effectively put the "service" work well, play well Colleges "Fuwuyuren" function " ${ }^{[3]}$. Multimedia voice equipment management and maintenance personnel, as well as groups of teachers colleges and universities multimedia voice classroom and other major users and operators of multimedia teaching equipment, whether it is to regulate the operations related to multimedia equipment for normal operation and can have a significant impact, once the improper operation, the light will affect the normal teaching order orderly conduct, heavy it may lead to major accidents unsafe, universities must therefore strengthen the 
voice of multimedia equipment management and maintenance personnel and a large group of teachers and public education, "Universities should explore mechanisms for managing staff training and classroom groups every year for teachers 1- 2nd training time can be placed at the beginning or end of the semester of school, but also on holiday. Training to operate the knowledge and skills-based, supplemented by theoretical study. " ${ }^{[4]}$, standardized multimedia equipment management and maintenance personnel, especially teachers use the operating behavior, in strict accordance with the use of multimedia devices normative procedures to be used, and resolutely put an end to the use of during any unconventional erroneous operation behavior, erroneous operation of behavior that may be present and personal discovery resolutely and prosecute them effectively supervise equipment management and maintenance personnel, and teachers groups operate strictly, improve equipment safety during sex.

6) Choose proper multimedia equipments including multimedia voice classroom multimedia equipments, and establish a stable system of multimedia equipment procurement and maintenance. With the increasingly common use of multimedia devices in colleges and universities, the current multimedia device market has also been a great development. all kinds of advanced multimedia devices on the market can be described as "dazzling", which makes a lot of colleges and universities in the selection of multimedia-related equipment the "worry", arbitrary large purchase of the equipment, the use of multimedia equipment in schools is often more brands, manufacturers have more, which to some extent, to the staff of multimedia equipment management and maintenance of the normal equipment brought practical difficulties, because different brands of multimedia devices are often differences in the operation, management and maintenance of large, so universities should establish a more stable source of multimedia equipment procurement mechanism, combined with the actual school choose one or two high credibility, high product quality manufacturers, manufacturers of the school as the main source of multimedia devices, "unified device model multimedia voice, multimedia teaching centralized procurement model unified voice classroom equipment models, to fully enhance the efficiency of the repair and maintenance of equipment." ${ }^{[5]}$, the school should actively establish long-term after-sales service system, and with the relevant manufacturers to solve the school in the presence of multimedia equipment inadequate maintenance, lack of technical and other issues, you can also take the opportunity to train school multimedia equipment management and maintenance personnel to effectively improve the level of maintenance and management of multimedia devices .

\subsection{Summary}

In short, the university multimedia voice classroom multimedia equipment plays an important role in today's regular teaching activities. Colleges and Universities multimedia voice classroom multimedia equipment management and maintenance is currently an important part of everyday life at university management. Universities should fully integrate the school the actual situation, effectively through a variety of effective measures to continue to strengthen the management of school multimedia equipment maintenance level, so as to effectively ensure the smooth teaching progress.

\section{References}

Song, W. G. (2014.06).Multimedia Classroom Management and Maintenance Explore[J] Hunan University of Science and Technology, 164-167.

Guan, C. J. (2011). Management and Maintenance of University Multimedia Voice Classrooms Network[J] Intelligence, 35, 247.

Shi, M. R. (2009.04) Quality of the Management of University Multimedia Voice Classroom[J] Shandong Youth Administrative Cadres College, 160-161.

Peng, J., \& Wang, H. F. (2007.11).Management and Maintenance of University Multimedia Classroom [J]. Chinese Modern Education Equipment, 137-138.

Deng, B. Q., \& FAN, H. B. (2014).Management of Multimedia Voice Classroom in Multimedia Teaching [J] Science and Technology Wind, 23, 254.

\section{(cc) EY}

This work is licensed under a Creative Commons Attribution 3.0 License. 